Int.J. Hum. Soc. Dev. Res.

ISSN (P):2521-1439; ISSN (E):2523-4331

Volume 3, № 1, 2019. 66-85

DOI: $10.30546 / 2523-4331.2019 .3 .1 .66$

\title{
EFFECTIVENESS OF TOURISM POTENTIAL OF ALTERNATIVE TOURISM DIVERSITY
}

\author{
Uzeyir YILDIZ \\ Southern University (IMBL) Russian Federation \\ Near East University, North Cyprus
}

(C) The Author(s) 2019

\begin{abstract}
In recent years, it has been seen that many alternative tourism models have emerged both in the world and in our country. These types of tourism that have gained importance within the scope of tourism product diversification have been influential in the search for innovations in tourism, the departure of today's tourists from noise and concrete piles, search for natural environment and quality service, increase of importance of tourism consciousness and education level. Among these alternative tourism types; cave, hunting, congress, thermal, faith, culture and so on. some local priorities and standards need to be met in order to be able to develop many tourist destinations. With this study, it has been tried to find out how this potential can be gained to the tourism sector by examining the alternative tourism potential of Antalya with its geopolitical position, past civilizations and cultured lands, important natural and cultural resources in the past. The research is important in terms of giving an idea about the alternative tourism potential of the Antalya region and showing the importance of the contributions that tourism can provide through the development of this potential and proposing solutions for this potential.During the implementation phase of the research, an area survey was conducted to determine the existing tourism potential for the domestic and foreign tourists and tourism operators and to identify and develop alternative tourism opportunities. Survey method was used as data collection technique in the study. The survey was conducted in three categories to be applied to 150 domestic tourists, 100 foreign tourists and 100 tourism operators. The obtained data were analyzed in SPSS program using percent, frequency, Chi-square and One-way ANOVA methods, and the results were tabled.As a result of the studies carried out in this framework, it is concluded that the Antalya region has sufficient alternative tourism potential to provide national and international tourism mobility but it can not benefit as much as this potential.
\end{abstract}

(C)2019.All rights reserved

ARTICLE HISTORY

Received: 07/12/2018

Accepted: 01/03/2019

Published online: 01/04/2019

\section{KEYWORDS}

Tourism, Alternative tourism, Antalya, international tourism,tourism models . 


\section{Introduction}

The tourism sector is at the forefront of the fastest growing and growing sectors in the world. As the boundaries go away, the world has begun to shrink, and people have tended to travel farther away. The rapid development of tourism activities in the world showed, both in Turkey and economic policies within both showed a very rapid growth in the tourism sector micro basis.

Tourism is a sector that triggers all sectors by creating multiplier effects on the economy in more dimensions than other sectors. So much so that the tourism activities in terms of the impact on employment, the role of the elimination of regional imbalances, the influence of the national holiday, the positive contribution of the payments and the socio-cultural influences have led to the establishment of these inland ministries, vocational schools and the creation of departments and even faculties in universities. For emerging economies, it is a "living similitude" in terms of foreign tourism revenues in closing the balance of payments surpluses.

Every year, the share of world tourism increases in production and at the same time the tourism movement is shifting from the west to the east. With this development, the share of the countries having tourism values from world tourism is also increasing. In line with the increase in income; increase in infrastructure investments and improvements in health and safety are among the important factors that played a role in the development of tourism. From this point of view, the cradle of great civilizations, our country's tourism revenues are increasing due to its strategic location, richness of sea-sand sunshine, rich culture and natural resources, and the share of world tourism is increasing. Besides the geographical and cultural wealth, as different from each other structure of each region in Turkey, which incorporates the feature of being a center of attraction.

It is clear that there is no obstacle for the affluence of the Anatolian geography, which is the cradle of civilizations, in the positive sense of the tourism movements. Although it is a modern city, its historical history, cultural and geographical richness of Antalya, which is not among the safest cities of our country and which has not got its share of tourism revenues, nature tourism, health tourism and congress tourism in terms of attractiveness as a center to bring out the nature of a work has been adopted.

Today our entrepreneurs to be rich cities such as Antalya city located in central Turkey, making the investment at an increasing rate each year to this city is a huge advantage. The fact that this advantage is reflected in the tourism sector and that 
Antalya is introduced to the world with all its qualities and beauty will benefit not only this city but also the surrounding provinces and cities as well.

\section{The Importance of Research}

Antalya; is a city that draws attention with its productions in the fields of natural resources, socio-cultural values, historical places, geographical position, industry and commerce. The ancient Seljuk capital Antalya, one of the first settlements of human history and bearing the traces of many civilizations in history, has an important potential that has been given more tourism every year with its natural beauties and historical places in its region.

The city, which has such a tourism potential, is in an important position in terms of alternative tourism besides belief and culture tourism. The research in this context is important in terms of giving the region an idea about the potential of alternative tourism, showing the importance of the contribution that tourism can provide through the development of this potential and offering solutions for this.

\section{Scope of the Research}

It is necessary to put forward the contributions that the possession potential can be uncovered, evaluated, developed and tourismed. The scope of this research is composed of the managers / entrepreneurs working in tourism enterprises operating in the Antalya region and the local and foreign tourists who came to the region.

\section{Purpose of the research}

- Factors affecting the length of stay of the local and foreign tourists visiting the region, reasons of preference of the region,

- To determine the opinions of local and foreign tourists and tourism operators about the promotion of the region and the problems about the tourism of the region,

- To identify alternative tourism types in which local and foreign tourists and tourism operators think that they can develop in the region and

- To reveal the thoughts of local and foreign tourists and tourism operators regarding the alternative tourism potential in the region.

\section{Research Method}

The survey was conducted in the form of a questionnaire survey among managers / entrepreneurs (restaurant, hotel, travel agency) working in tourism enterprises operating in the Antalya region and domestic and foreign tourists visiting the region. Face-to-face 
survey method has been preferred in order to be able to work more efficiently and to provide fast recycling.

\section{The content of the research}

An area survey has been carried out for the determination of existing tourism potential, determination of alternative tourism potential and development of this potential for domestic and foreign tourists and tourism operators. During the implementation phase of the study, attempts were made to determine the opinions of domestic and foreign tourists and tourism operators regarding alternative tourism potential in Antalya. As a result of the research, the findings are analyzed and suggestions for revealing alternative tourism potential in Antalya region are presented.

\section{Tourism Definition and Basic Characteristics}

Nowadays, millions of people go to other countries or regions for temporary separation from their permanent places and meet their psychological, social and cultural needs such as sight-seeing, resting, learning-learning. This phenomenon, which has broad economic and social effects and is considered tourism, constitutes a fundamental characteristic of today's civilization (Uçkun, 2004:28).

It is said that tourism is produced from the root of "tornus" which means to return to Latin, to circulate around, to return. The word "turnaround", which has entered my Turkic language, is based on the same root. As is known, the promise to turn around; to turn back, to turn around, to turn inside out (Sezgin, 2001:13). If we look at various descriptions of tourism concept; Tourism is a humanitarian activity that leads to a certain destination by way of a provincial route for rest or business. It is a complex whole of economic, cultural, social and technological items from the beginning of travel (Tekeli, 2001:3).

Tourism is an activity related to meeting the needs of temporary accommodation in places where people travel and where they live outside the place they have always lived (Batman, 2008:3).

In a basic sense, tourism is an event in which people visit places of interest, friends, relatives, tours and good times. People can appreciate their free time with various sports, sun bathing, chatting, going out on a tour, reading a book or singing, or simply enjoying it (Ünüsan ve Sezgin, 2005:131). 
International Association of Scientific Tourism Experts (AIEST) has defined the concept of tourism in 1980 as follows; travels outside the places where people live, work, meet their usual needs and consume the goods and services produced by the tourism enterprises there; the activities arising from temporary accommodation (Öztaş, 2002:2).

\section{Tourist Definition and Basic Features}

The tourist word is derived from the word "tour" which is of English origin and meaning tour. The word of the tour is a cyclical journey that starts from a certain place and expresses that the result of travel is to return to the same place again. When it comes to a lot of tourists, we think of a person on holiday who visits a remote area for the purpose of seeing the surroundings, visiting friends and relatives, resting away from the daily stratagem. Many people consider tourists as people who travel for vacation. However, apart from the purpose of making a holiday, there are many tourist groups that participate in tourism. For example; business world, conference delegates and others (S1klar, 1994:2).

Tourism, which is the subject of tourism, is participating in tourism to provide psychological satisfaction. The person who leads the tourism event, directs it and constitutes the subject of this event is called "tourist". (Aktaş, 2002:2).

In other words, tourists; a person who travels out as a consumer, returns to where he or she once lived, and returns for a temporary period of time and psychological satisfaction outside the permanent place of permanent residence (Batman ve Soyball, 2009:29).

\section{Materials and Methods \\ The Purpose and Importance of Research}

The purpose of the research is to examine the tourism potential of the Antalya region and to elucidate how the potential of the Antalya region can be gained by taking this potential into consideration in the tourism sector by considering the alternative tourism opportunities in detail. In this context, if there are "alternative tourism types other than belief tourism in Antalya region", it is searched if the question "can these types of tourism be effective in spreading tourism activities of the region and increasing tourism potential of the province?" This survey aims to reach the following objectives with the survey study applied to domestic and foreign tourists and tourism operators:

- The age, gender, education and income situation of domestic and foreign tourists and tourism operators who prefer the region, 
- Domestic and foreign tourists to or from the region,

- The average duration of stay of local and foreign tourists in the region, the factors affecting the duration of stay,

- The main factors that play a role in the choice of local and foreign tourists,

- The incidence of local and foreign tourists to the region, the tendency to come back to the region and the reasons for this,

- Alternative tourism varieties where domestic and foreign tourists and tourism operators think that they can develop in Antalya,

- According to local and foreign tourists and tourism operators, the problems of getting the region into tourism and the ideas about the promotion of the region,

- The opinions of the administrators / entrepreneurs about what can be done to create the demand for tourism in the Antalya region,

- Considerations of domestic and foreign tourists and tourism operators regarding alternative tourism potential in Antalya.

- The research is important in terms of giving an idea about the alternative tourism potential of the Antalya region and revealing the importance of the contributions that tourism can provide by developing this potential. In the conclusion of the survey, suggestions for improving the alternative tourism potential in the region are also presented.

\section{Scope of the Study}

The universe of the research is composed of managers / entrepreneurs working in tourism enterprises (restaurant, hotel, travel agency) operating in the Antalya region and domestic and foreign tourists who came to the region from the region. 100 adjectives from 120 surveys presented to the tourism operators (restaurant, hotel, travel agency) participating in the survey study using the sampling method easily, 150 adjectives from 175 surveys presented to local tourists visiting the Antalya region and 100 surveys presented to foreign tourists and 420 surveys distributed from 100 surveys The number of valid questionnaires were taken into consideration. These surveys have been implemented between 10-17 December 2008 in the region and abroad by tourists and entrepreneurs working in tourism enterprises operating in the region.

\section{Data Collection Method}

The survey was carried out in three categories, namely managers / entrepreneurs (restaurant, hotel, travel agency) working in tourism enterprises operating in the Antalya region and local and foreign tourists who came to the region in the form of a survey. The survey form used in the research was inspired by Mete Sezgin's work in 2004 and 
Kadir Öztaş's work in 1997. Face-to-face survey method has been preferred in order to be able to work more efficiently and to provide fast recycling. In the first part of the questionnaire, a number of closed-ended questions were asked to determine the opinions of tourists and tourism operators about their demographic characteristics and tourism potentials in the region. In the second part, 12 judicial opinions including alternative tourism potentials were given. A 5-point Likert scale was used to take into account these judgments. Accordingly, the second part of the questionnaire includes options for $1=$ strongly agree, $2=$ agree, $3=$ undecided, $4=$ disagree and $5=$ strongly disagree.

\section{Data Analysis Method}

The obtained data were analyzed in the SPSS program using percent, frequency, Chi-square and One-way ANOVA methods. The results were tabulated and evaluated. When the questionnaires were evaluated, the answers of all the questions given to the questionnaire were given in different tabs in the study; the percentages of the distribution of the result are given numerically and in tabular form.

\section{Analysis and Findings of Research Data}

The questions related to domestic and foreign tourists and tourism operators were grouped and the research findings and evaluations in the same scope were grouped as follows.

Table 1: Gender characteristics of local tourists participating in the survey $(n=150)$

\begin{tabular}{lcc}
\hline Gender & n & \% \\
\hline Male & 73 & 48,6 \\
Woman & 77 & 51,4 \\
\hline
\end{tabular}

According to the Table 1 prepared based on the survey of the domestic tourists who participated in the survey, a total of 150 persons including 73 males and 51 females with a ratio of $48,6 \%$ were participated in the survey. 
Table 2: Age characteristics of domestic tourists participating in the survey $(n=150)$

\begin{tabular}{lll}
\hline Ages & n & \% \\
\hline $15-24$ & 34 & 22,6 \\
$25-34$ & 49 & 32,7 \\
$35-44$ & 41 & 27,3 \\
$45-54$ & 26 & 17,4 \\
\hline
\end{tabular}

While $32.7 \%$ of the tourists participating in the survey are in the age range of 25 $34,27.3 \%$ are in the age group of $35-44$ and $22.6 \%$ are in the age group of $15-24$.

Table 3: Educational Characteristics of Domestic Tourists Participating in the Survey $(\mathbf{n}=\mathbf{1 5 0})$

\begin{tabular}{lll}
\hline Education Status & $\mathbf{n}$ & \% \\
\hline Primary education & 10 & 6,7 \\
Secondary education & 16 & 10,7 \\
High school & 17 & 11,3 \\
University & 95 & 63,3 \\
Graduate & 12 & 8,0 \\
\hline
\end{tabular}

When it comes to the educational situation, it is seen that $63.3 \%$ of domestic tourists are university graduates and $11.3 \%$ are high school graduates. $8,0 \%$ of the students have graduate education.

Table 4: Occupational Status Characteristics of Domestic Tourists Attending the Survey $(\mathbf{n}=\mathbf{1 5 0})$

\begin{tabular}{lll}
\hline Occupational Status & $\mathbf{n}$ & $\mathbf{\%}$ \\
\hline Student & 29 & 19,3 \\
Self-employment & 35 & 23,4 \\
Retired & 8 & 5,3 \\
Worker & 3 & 2,0 \\
Teacher & 17 & 11,4 \\
Officer & 35 & 23,4 \\
Unemployed & 4 & 2,6
\end{tabular}


Other

12,6

When the distributions according to professional groups are examined, while $23.4 \%$ of them are self-employed and civil servants, $19.3 \%$ of them are followed by students.

Table 5: Income Status Characteristics of Indigenous Tourists Participating in the Survey $(\mathbf{n}=\mathbf{1 5 0})$

\begin{tabular}{lll}
\hline Income Status & & \\
\hline 750 TL Less than & 16 & 10,6 \\
$750-1.000 \mathrm{TL}$ & 40 & 26,6 \\
$1.001-2.000 \mathrm{TL}$ & 62 & 41,3 \\
$2.001-3.000 \mathrm{TL}$ & 27 & 18,0 \\
3.001 TL More than & 5 & 3,5
\end{tabular}

When the distribution according to the monthly incomes of the participants is examined, it is seen that those who have a income from $41.3 \%$ to $1.001-2.000 \mathrm{TL}$ in the first place, those who have a income from $26.6 \%$ to $750-1.000$ TL in the second place and those who have a income from $18.00 \%$ to $2.001-3.000$ There are those who have income between TL and TL.

Table 6: Gender characteristics of foreign tourists participating in the survey

\begin{tabular}{ccc}
$(\mathbf{n}=\mathbf{1 0 0})$ & $\mathbf{n}$ & $\mathbf{\%}$ \\
\hline Gender & 54 & 54,0 \\
\hline Male & 46 & 46,0
\end{tabular}

According to Table 6, which was prepared based on the data of the foreign tourists participating in the survey, a total of 100 people participated in the survey, 54 men and 54 women with $46.0 \%$ and $46.0 \%$ respectively.

Table 7: Age characteristics of foreign tourists participating in the survey $(n=$ 100)

\begin{tabular}{lll}
\hline Age & n & \% \\
\hline $15-24$ & 4 & 4,0 \\
$25-34$ & 14 & 14,0
\end{tabular}




$\begin{array}{lll}35-44 & 33 & 33,0 \\ 45-54 & 22 & 22,0 \\ 55+ & 27 & 27,0\end{array}$

While $33.0 \%$ of the tourists participating in the survey were in the age range of 35 $44,27.0 \%$ were in the age group of $55+, 22.0 \%$ in $45-44$ and $14.0 \%$ in 15 age group.

Table 8: Educational Characteristics of Foreign Tourists Participating in the Survey $(\mathbf{n}=\mathbf{1 0 0})$

\begin{tabular}{lll}
\hline Education Status & $\mathbf{n}$ & $\mathbf{\%}$ \\
\hline Secondary education & 6 & 6,0 \\
High school & 16 & 16,0 \\
University & 63 & 63,0 \\
Graduate & 15 & 15,0 \\
\hline
\end{tabular}

When it is considered in terms of educational status, it is seen that $63.0 \%$ of foreign tourists are university graduates and $16.0 \%$ are high school graduates. $15,0 \%$ of the students have received post-graduate education.

Table 9: Occupational Status Characteristics of Foreign Tourists Participating in the Survey $(n=100)$

\begin{tabular}{lll}
\hline Occupational Status & n & \% \\
\hline Student & 8 & 8,0 \\
Self-employment & 14 & 14,0 \\
Retired & 30 & 30,0 \\
Worker & 19 & 19,0 \\
Teacher & 14 & 14,0 \\
Officer & 11 & 11,0 \\
Other & 4 & 4,0 \\
\hline
\end{tabular}


When the distributions according to occupational groups are examined, while the retirement with $30.0 \%$ is in the first place, this rate is followed by $19.0 \%$ with workers.

Table 10: Income Status Characteristics of Foreign Tourists Participating in the Survey $(n=100)$

\begin{tabular}{lll}
\hline Income Status & & \\
\hline $750-1.000 \mathrm{TL}$ & 8 & 8,0 \\
$1.001-2.000 \mathrm{TL}$ & 21 & 21,0 \\
$2.001-3.000 \mathrm{TL}$ & 45 & 45,0 \\
3.001 More than TL & 24 & 24,0 \\
\hline
\end{tabular}

When the distribution according to monthly incomes of the participants is examined, it is seen that those who have a income from $45.0 \%$ to 2.001-3.000 TL in the first place, those who have a income from $24.0 \%$ to 3.001 TL in the second place and those who have income between $21.0 \%$ and $1.001-2.000 \mathrm{TL}$ in the third place.

Table 11: Opinions of Domestic-Foreign Tourists and Tourism Operators on Alternative Tourism Potential in Antalya

\begin{tabular}{|c|c|c|c|c|c|}
\hline & Group & & $\bar{X}$ & $\begin{array}{l}\text { Sta } \\
\text { ndard } \\
\text { deviation }\end{array}$ & $\begin{array}{l}\text { Importance } \\
\text { level }\end{array}$ \\
\hline \multirow{3}{*}{$\begin{array}{l}\text { Caves located in and around } \\
\text { Antalya are marketed in alternative } \\
\text { tourism. }\end{array}$} & Domestic & 50 & 3,43 & 1,0 & MIDDLE \\
\hline & Foreign & 00 & 3,29 & 1,0 & MIDDLE \\
\hline & Operating & 00 & 3,46 & 1,0 & MIDDLE \\
\hline \multirow{3}{*}{$\begin{array}{l}\text { Antalya has sufficient tourism } \\
\text { potential in terms of other alternative } \\
\text { tourism types besides belief tourism. }\end{array}$} & Domestic & 50 & 1,84 & 0,9 & HIGH \\
\hline & Foreign & 00 & 2,03 & 1,1 & $\mathrm{HIGH}$ \\
\hline & Operating & 00 & 1,88 & 1,0 & HIGH \\
\hline \multirow{3}{*}{$\begin{array}{l}\text { Specialized travel agencies that } \\
\text { deal with special types of tourism such } \\
\text { as congress, health, thermal are } \\
\text { sufficient. }\end{array}$} & Domestic & 50 & 3,58 & 1,0 & MIDDLE \\
\hline & Foreign & 00 & 3,45 & 1,1 & MIDDLE \\
\hline & Operating & 00 & 3,41 & 1,1 & MIDDLE \\
\hline \multirow{2}{*}{$\begin{array}{l}\text { Antalya's alternative tourism } \\
\text { destination and region promotion is } \\
\text { being done sufficiently. }\end{array}$} & Domestic & 50 & 3,87 & 0,9 & LOW \\
\hline & Foreign & & 3,97 & 0,9 & LOW \\
\hline
\end{tabular}




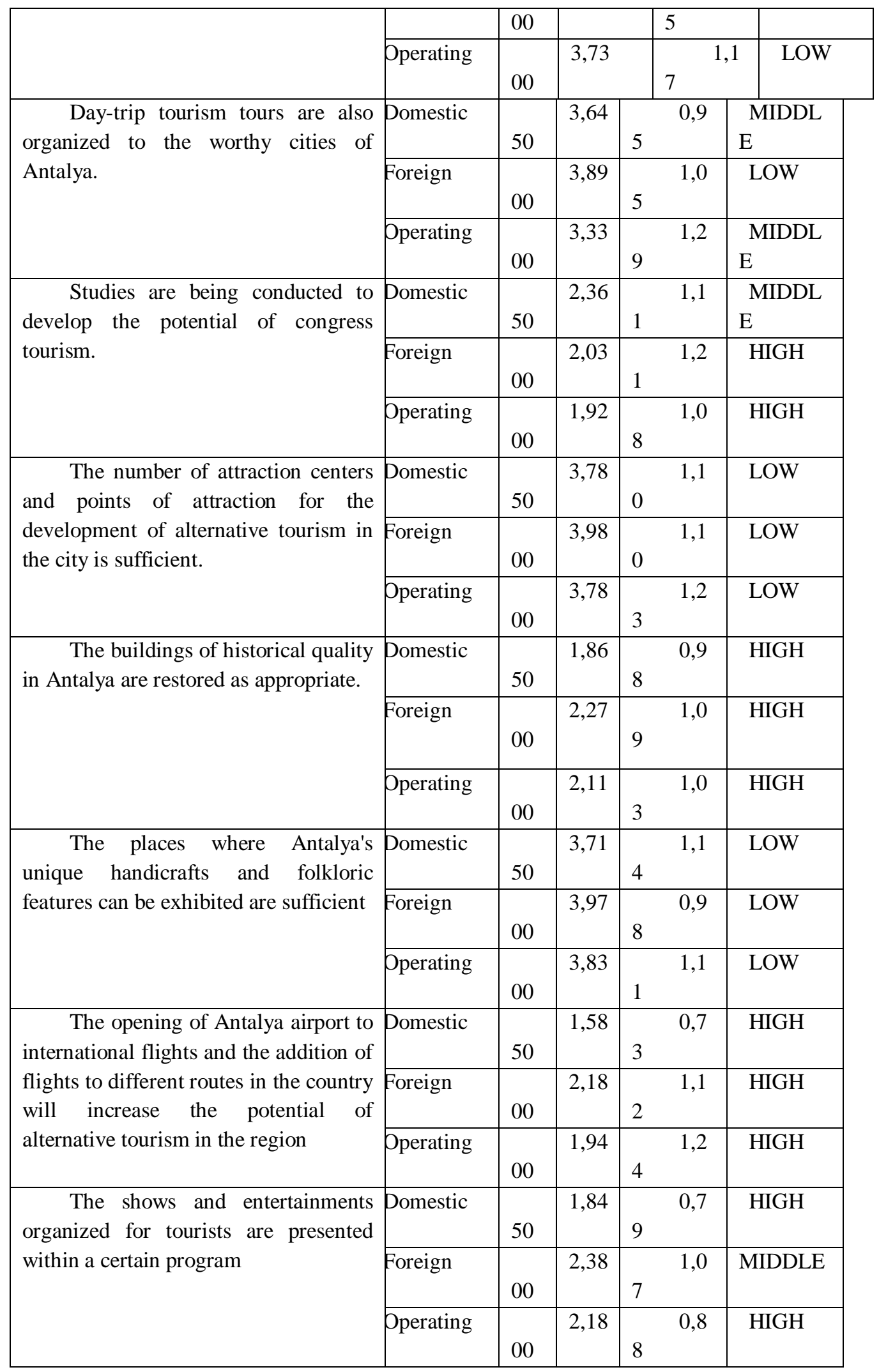




\begin{tabular}{|c|c|c|c|c|c|}
\hline \multirow{3}{*}{$\begin{array}{l}\text { In Antalya, infrastructure and } \\
\text { superstructure works are carried out in } \\
\text { order to reach the desired level of } \\
\text { alternative tourism varieties. }\end{array}$} & Domestic & 50 & 1,84 & $\begin{array}{ll} & 0,9 \\
5 & \end{array}$ & IIGH \\
\hline & Foreign & 00 & 2,75 & 1,2 & AIDDLE \\
\hline & Operating & 00 & 2,42 & 1,0 & KIDDLE \\
\hline
\end{tabular}

(High if $X=1.00-2.33$, Medium if $X=2.34-3.66$, Low if $X=3.67-5.00$ )

Table 11 gives the average values, standard deviation values and levels of importance of the participation rates of domestic and foreign tourists and tourism operators regarding the alternative tourism potential in Antalya. In this context, it is seen that "caves in Antalya and its surroundings are being marketed in alternative tourism" and they are largely unstable in all three groups.

"Antalya has enough tourism potency in terms of other alternative tourism types besides belief tourism", but the participation rates of the groups have been high. Domestic and foreign tourists and businessmen have agreed that the region has sufficient potential in terms of alternative tourism diversity but that there is not enough destination and regional promotion for this. From this point of view, the participation rates are low because of the suggestion that "Antalya has enough destinations and destinations for alternative tourism".

The importance level of the suggestion "the number of attraction centers and attractive points for the development of alternative tourism in the city is sufficient" has been determined at a low level. It is seen that the majority of tourism operators and tourists are hesitant to recommend that "specialized travel agencies that deal with special types of tourism such as congress, health, thermal are sufficient". While they have high participation in the restoration of historical buildings in Antalya, they think that the places where Antalya's unique handicrafts and folkloric features can be exhibited are not enough.

According to the groups, the importance level of "Antalya airport opening to international flights and increasing the potential of alternative tourism in the region where airplanes are put on different routes in the country" has been determined at a high level.

The importance of suggesting that "Congress is working to develop tourism potential" has been determined at a high level in terms of foreign tourists and tourism operators, and local tourists have been hesitant to make this recommendation. "The infrastructure and superstructure works necessary for the alternative tourism types to reach the desired level are realized in Antalya" while local tourists are participating at high level while the participation ratings of foreign tourists and tourism operators are determined at the middle level. 
While "daily tourism tours are organized to the worthy provinces of Antalya", local tourists and tourism operators are undecided, and the level of participation of foreign tourists is low. Foreign tourists have participated in the middle level, while local tourists and businessmen have shown a great deal of participation in the proposal that "the shows and entertainment organized for the tourists are presented within a certain program".

Table 12: Comparison of Alternative Tourism Potential Opinions of Antalya in terms of Domestic-Foreign Tourists and Tourism Operators

\begin{tabular}{|c|c|c|c|c|c|}
\hline & Grup & $\bar{X}$ & $\begin{array}{l}\text { Sta } \\
\text { ndard } \\
\text { deviation }\end{array}$ & & ig. \\
\hline \multirow[t]{3}{*}{$\begin{array}{l}\text { Caves located in and around Antalya } \\
\text { are marketed in alternative tourism. }\end{array}$} & Domestic & ,43 & $\begin{array}{ll} & 1,0 \\
8 & \end{array}$ & \multirow{3}{*}{,75 } & \multirow{3}{*}{,49 } \\
\hline & Foreign & ,29 & 1,0 & & \\
\hline & Operating & ,46 & 1,0 & & \\
\hline \multirow{3}{*}{$\begin{array}{l}\text { Antalya has sufficient tourism potential } \\
\text { in terms of other alternative tourism types } \\
\text { besides belief tourism. }\end{array}$} & Domestic &, 84 & 0,9 & \multirow{3}{*}{,03 } & \multirow{3}{*}{, 37} \\
\hline & Foreign & ,03 & 1,1 & & \\
\hline & Operating &, 88 & 1,0 & & \\
\hline \multirow{3}{*}{$\begin{array}{l}\text { Specialized travel agencies that deal } \\
\text { with special types of tourism such as } \\
\text { congress, health, thermal are sufficient. }\end{array}$} & Domestic &, 58 & 1,0 & \multirow{3}{*}{,92 } & \multirow{3}{*}{,41 } \\
\hline & Foreign &, 45 & 1,1 & & \\
\hline & Operating & ,41 & 1,1 & & \\
\hline \multirow{3}{*}{$\begin{array}{l}\text { Antalya's alternative tourism } \\
\text { destination and region promotion is being } \\
\text { done sufficiently. }\end{array}$} & Domestic &, 87 & 0,9 & \multirow{3}{*}{,43 } & \multirow{3}{*}{, 25} \\
\hline & Foreign & ,97 & 0,9 & & \\
\hline & Operating &, 73 & 1,1 & & \\
\hline \multirow[t]{3}{*}{$\begin{array}{l}\text { Day-trip tourism tours are also } \\
\text { organized to the worthy cities of Antalya. }\end{array}$} & Domestic & ,64 & 0,9 & \multirow{3}{*}{, 83} & \multirow{3}{*}{, 01} \\
\hline & oreign & ,89 & 1,0 & & \\
\hline & perating & ,33 & $\begin{array}{ll} & 1,2 \\
8 & \end{array}$ & & \\
\hline
\end{tabular}




\begin{tabular}{|c|c|c|c|c|c|}
\hline \multirow[t]{4}{*}{$\begin{array}{l}\text { Studies are being conducted to develop } \\
\text { the potential of congress tourism. }\end{array}$} & omestic &, 36 & $\begin{array}{ll} & 1,1 \\
0 & \end{array}$ & \multirow{4}{*}{,22 } & \multirow{4}{*}{, 02} \\
\hline & oreign & & 1,2 & & \\
\hline & & 03 & 0 & & \\
\hline & perating & ,92 & $\begin{array}{ll} & 1,0 \\
7 & \end{array}$ & & \\
\hline \multirow{4}{*}{$\begin{array}{l}\text { The number of attraction centers and } \\
\text { points of attraction for the development of } \\
\text { alternative tourism in the city is sufficient }\end{array}$} & omestic & ,78 & 1,0 & \multirow{4}{*}{, 25} & \multirow{4}{*}{, 30} \\
\hline & oreign & & 1,0 & & \\
\hline & & ,98 & 9 & & \\
\hline & perating & ,78 & 1,2 & & \\
\hline \multirow[t]{4}{*}{$\begin{array}{l}\text { The buildings of historical quality in } \\
\text { Antalya are restored as appropriate. }\end{array}$} & omestic & ,86 & 0,9 & \multirow{4}{*}{, 16 } & \multirow{4}{*}{, 02} \\
\hline & oreign & & 1,0 & & \\
\hline & & ,27 & 8 & & \\
\hline & perating &, 11 & 1,0 & & \\
\hline \multirow{4}{*}{$\begin{array}{l}\text { The places where Antalya's unique } \\
\text { handicrafts and folkloric features can be } \\
\text { exhibited are sufficient }\end{array}$} & omestic & ,71 & 1,1 & \multirow{4}{*}{,77 } & \multirow{4}{*}{, 18} \\
\hline & oreign & & 0,9 & & \\
\hline & & ,97 & 7 & & \\
\hline & perating &, 83 & 1,1 & & \\
\hline \multirow{3}{*}{$\begin{array}{l}\text { The opening of Antalya airport to } \\
\text { international flights and the addition of } \\
\text { flights to different routes in the country will } \\
\text { increase the potential of alternative tourism } \\
\text { in the region }\end{array}$} & omestic &, 58 & 0,7 & \multirow{3}{*}{1,7} & \multirow{3}{*}{, 00} \\
\hline & oreign & ,18 & 1,1 & & \\
\hline & perating & ,94 & 1,2 & & \\
\hline \multirow{3}{*}{$\begin{array}{l}\text { The shows and entertainments } \\
\text { organized for tourists are presented within a } \\
\text { certain program }\end{array}$} & omestic &, 84 & 0,7 & \multirow{3}{*}{1,9} & \multirow{3}{*}{,00 } \\
\hline & oreign & ,38 & 1,0 & & \\
\hline & perating & ,18 & 0,8 & & \\
\hline \multirow{3}{*}{$\begin{array}{l}\text { In Antalya, infrastructure and } \\
\text { superstructure works are carried out in order } \\
\text { to reach the desired level of alternative } \\
\text { tourism varieties. }\end{array}$} & omestic & ,84 & 0,9 & \multirow{3}{*}{, 42} & \multirow{3}{*}{, 00} \\
\hline & oreign &, 75 & 1,1 & & \\
\hline & perating & ,42 & 1,0 & & \\
\hline
\end{tabular}


Table 12 compares the opinions of domestic and foreign tourists and tourism operators regarding alternative tourism potential in Antalya. According to this table; There is a difference between groups (local tourists, foreign tourists, tourism operators) regarding the suggestion that "daily tourism tours are organized to the worthy provinces of Antalya". The participants' opinions on "daily tourism tours are organized to the worthy provinces of Antalya" vary according to local and foreign tourists and tourism operators participating in the survey $(\mathrm{p}<0.01)$. According to this; foreign tourists, domestic tourists and tourism operators. There is a distinction between groups (local tourists, foreign tourists, tourism operators) regarding the proposal that "Congress is working to develop tourism potential". Participant opinions on "Congress is making efforts to improve the tourism potential" vary according to the domestic and foreign tourists and tourism operators participating in the survey $(\mathrm{p}<0.01)$. According to this; local tourists, foreign tourists and tourism operators. There is a distinction between groups (local tourists, foreign tourists, tourism operators) regarding the suggestion that "the buildings with historical characteristics in Antalya are restored as appropriate". The participant opinions on "the buildings with historical characteristics in Antalya are restored as appropriate" differ according to the domestic and foreign tourists and tourism operators participating in the survey $(\mathrm{p}<0,01)$. According to this; foreign tourists, domestic tourists and tourism operators. There is a difference between the groups (local tourists, foreign tourists, tourism operators) regarding the suggestion that "Antalya airport should be opened to international flights and air travel to different routes in the country will increase the potential of alternative tourism in the region". "Participating opinions on the opening of Antalya airport to international flights and increasing the potential of alternative tourism in the region where airplanes are put on different routes in the country" are different according to the domestic and foreign tourists and tourism operators participating in the research.

\section{Conclusions and Recommendations}

Alternative tourism is becoming increasingly widespread throughout the world. New trends in the world and pollution on natural systems are an important factor in the emergence of new trends in tourism. On the other hand, the uniformity in social and business life also increases the demand for alternative tourism activities. Countries frequently use product differentiation strategies in marketing activities. Alternative tourism and new tourist products have increased their importance for this reason. These concepts are extremely important in terms of sustainability for tourism regions. The Antalya region is also a province with sufficient potential in terms of alternative tourism in order to be one of the important centers of Turkish tourism. When we evaluate the results of the application phase of the study to assess the alternative tourism potential of the Antalya region and to examine the effect of this potential on the tourism of the region, The main difficulty in getting the region into tourism according to the domestic 
and foreign tourists and tourism operators who have come to Antalya is that there is not enough publicity.

In this context, an effective and effective promotion policy should be followed in order to get a share from the tourism market and increase the share of ownership, to use written and oral media tools, to use natural beauties that the region has and to use alternative tourism varieties such as congress tourism, cultural tourism, promotional activities should be made for other types of tourism. It should be tried to develop in the form of supportive tourism varieties as an alternative to evaluating the leisure time of the tourists who are mainly in the frame of belief tourism.

Local and foreign tourists who participated in the survey answered "Cultural tourism" in the question of which alternative tourism types other than belief tourism can be developed in the Antalya region and "tourism tourism" in the tourism operators. Accordingly, in order to increase the variety of products in the sector and to develop other alternative tourism types, investments towards alternative tourism types such as golf, health, thermal, mountain, plateau, winter, youth, botanical and jeep safari should be encouraged and encouraged.

As the most important factor affecting the duration of the stay in the region, "tourism is limited only to belief tourism" and "tourism operators" are the reasons why tourists stay in the region for a short period of time.

Tourists and tourism operators seem to agree that there is sufficient potential in the region in terms of alternative tourism diversity. However, this potential can not be fully evaluated. Antalya, which is located in the south of Anatolia, is not only suitable for religious tourism, besides cultural tourism; it is believed that congress tourism with a good presentation will develop the tourism of nature with its rich nature and that the cultural heritage of its people can also create a gravitational force. For this reason, diversification of tourism investments should be done in order to spread the tourism activities to all areas by shifting to other fields besides faith tourism.

In all three groups, they were unsure whether the number of specialized travel agencies dealing with specific types of tourism such as congress, health, and thermal was sufficient. For this purpose; studies should be carried out in order to increase the number of specialized travel agencies in the field so that the promotion of the richness of the region's wealth in national and international environment can be done in a good way and that Antalya can take more places in the routes of domestic and foreign tour organizations. In addition, training of specialized tourist guides who are aware of all the features of the region and developing themselves in this direction and immediate resolution of issues such as encouragement of local travel agency will play an important role in the development of the alternative tourism potential of the region. 
In all three groups, they agreed that Antalya was not sufficiently promoting alternative tourism destinations and regions. It is necessary to open Antalya to the world, to introduce our historical and cultural values, to make the necessary infrastructure, environmental regulation and effective publicity work as soon as possible and to gain tourism in the region. For this purpose; in order to make the promotion of the region effectively, to make the national and international promotion of the region effective, to increase the qualifications of the accommodation facilities and in particular to the tourism and recreation resources in the province in general, together with the travel agencies, the local administrations, the Antalya Provincial Culture and Tourism Directorate and the associations' it is necessary to improve the existing infrastructure in the province for accessibility, which is one of the most important factors in tourism, to provide a balanced distribution in accordance with the natural and cultural texture of the region. Thus, the presentation of Antalya to my country and the outside world will be realized more.

It is seen that in all three groups, the number of attraction centers and attracting points for the development of alternative tourism in the city is considered to be insufficient. However, with its rich, natural and cultural assets, the Antalya region, which has the most distinguished history and cultural treasures of the world, is an important attraction center for tourism and recreational activities at national and international level. The discovery of these riches of Antalya, which is almost entirely a nature, a historical and cultural treasure, and the immediate elimination of existing shortcomings will increase the likelihood of having a large share of the tourism income in the region in the coming years. It seems that the majority of domestic tourists are undecided while foreign tourists and tourism operators are working on the development of congress tourism. Antalya also has a great potential for congress tourism. But he has not got the share he deserves from congress tourism. Whereas congress tourism means coming from a pen that has never entered Antalya. In this respect, the potential possessed should be assessed, technical and financial support should be provided in terms of promotion and marketing, and a good planning system for congress tourism should be introduced. In addition, as one of the sectoral incentives of Antalya investors who are not among the encouraged provinces, there is a continuing expectation of support for congress tourism. In each of the three groups, the opening of Antalya airport to international flights and the introduction of flights to different routes in the country will increase the potential for alternative tourism in the region.

The provision of civil status to the airport, the introduction of aircraft flights on different routes in the country and the opening of international flights, can make visible increases in the number of tourists visiting the region, and such a project can make Antalya a fair and congress center. In addition, the project should be prepared in a structure that will appeal to other objects that are integral with Antalya. On the other hand, the existing military airport remains within the city. For this reason, the existing 
military airport should be transported to the Karapınar area and the airport in the center should be transformed into a civilian airport. Indicators and entertainments organized for tourists are presented within a specific program. While foreign tourists are indecisive, local tourists and tourism operators are united in the view that the shows and entertainments are realized within a certain program. Foreign tourists are united in the opinion that daily tourism tours are not arranged for the cities while domestic tourists and tourism operators are indecisive about day trip tourism tours to the spectacular sights of Antalya. However, Antalya has many touristic places worth seeing in its districts. In order to evaluate the existing tourism potentials in the districts, effective promotions for these sites should be realized. There is a cave with many touristic potentials in the region. These caves need to be arranged according to the projects that will be produced by specialists of the subject, allowing them to easily navigate and visit. One of the potential needs of Antalya is thermal tourism.

\section{Disclosure statement}

No potential conflict of interest was reported by the author.

\section{Contact Information}

E-mail: uzeyir.yildiz@gmail.com 


\section{References and notes:}

Aktaş, A. 2002, Turizm İşletmeciliği ve Yönetimi, 2. Baskı, Detay Yayıncılık, Antalya.

Batman, O. ve Soybalı H. H. 2009, Otel İşletmeleri, Editörler: Demirkol, S., ve Zengin, B., Turizm İşletmeleri, Değişim Yayınları, İstanbul.

Batman, O. 2008, Otel İşletmelerinin Yönetimi, 3. Baskı, Değişim Yayınları, İstanbul.

Öztaş, K. 2002, Turizm Ekonomisi Genel Turizm Bilgileri, 1. Basım, Nobel Yayınları, Ankara.

Öztaş, K. 2002, Turizm Sektöründe Mutfak Hizmetleri, Nobel Yayınları, Ankara.

Öztaş, K, 1997, İç Anadolu Bölgesi Turistik Arz Kaynaklarının Dış Turizm Talebi Üzerine

Etkileri, Basılmamış Doktora Tezi, Dokuz Eylül Üniversitesi, Sosyal Bilimler Enstitüsü.

Sezgin, O. M. 2001, Genel Turizm ve Turizm Mevzuatı, Detay Yayıncılık, Ankara.

Tekeli, H. 2001, Turizm Pazarlaması ve Planlaması, Detay Yayıncılık, Ankara.

Uçkun, S. 2004, İşletme ve İşletme Türleri”, Editörler: Demirkol, S., ve B. Zengin, Turizm İşletmeleri, Değişim Yayınları, İstanbul.

Ünüsan, Ç. ve Sezgin, M. 2005, Turizmde Strateji Eksenli Pazarlama İletişimi, 1. Bask1, Nüve Kültür Merkezi Yayınları, Konya. 